\title{
Long-term dietary antioxidant cocktail supplementation effectively reduces renal inflammation in diabetic mice
}

\author{
Na-Young Park, Seul-Ki Park and Yunsook Lim* \\ Department of Food and Nutrition, College of Human Ecology, Kyung Hee University, 1 Hoegi-dong, Dongdaemun-gu, \\ Seoul 130-701, Republic of Korea
}

(Received 5 October 2010 - Revised 28 February 2011 - Accepted 14 March 2011 - First published online 3 June 2011)

\section{Abstract}

Diabetic nephropathy is a serious complication for diabetic patients, yet the precise mechanism that underlies the development of diabetic complications remains unknown. We hypothesised that dietary antioxidant supplementation with single $N$-acetylcysteine (NAC) or vitamin $\mathrm{C}$ combined with either vitamin $\mathrm{E}$ or vitamin $\mathrm{E}$ and NAC improves diabetic renal inflammation through the modulation of blood glucose levels, oxidative stress and inflammatory response. Experimental animals were treated with alloxan monohydrate to induce diabetes. Mice were divided into five groups and supplemented with single or a combination of antioxidants. Body weights and blood glucose levels were measured once a week. After 8 weeks of dietary antioxidant supplementation, mice were killed and blood urea N (BUN) and plasma crea-

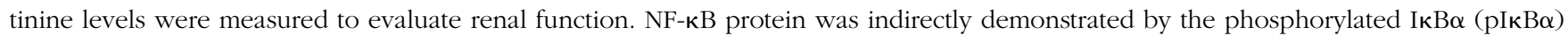
level, and the expressions of oxidative stress- and inflammatory response-related proteins were also determined. We demonstrated that dietary antioxidant supplementation decreased lipid peroxidation levels demonstrated by thiobarbituric acid-reacting substances, BUN and plasma creatinine levels in diabetic kidneys. Moreover, dietary antioxidant cocktail supplementation improved blood glucose levels and selectively regulated the expressions of $\mathrm{Cu}-\mathrm{Zn}$ superoxide dismutase, haeme oxygenase-1, pIкB $\alpha$, inducible $\mathrm{NO}$ synthase, cyclo-oxygenase- 2 and C-reactive protein in diabetic kidneys effectively. These findings demonstrated that diabetic renal failure was associated with inflammatory responses induced by hyperglycaemia. In addition, results in the study suggest that antioxidant cocktail supplementation may have beneficial effects on diabetic nephropathy through selective reduction of blood glucose levels and inflammatory response.

Key words: Diabetic nephropathy: Antioxidants: Oxidative stress: Inflammation: Diabetes mellitus

Diabetic nephropathy is one of the most serious long-term complications in terms of morbidity and mortality in diabetic patients $^{(1)}$. Although hyperglycaemia is considered as the prime metabolic aberrance, numerous other mechanisms have also been suggested for the development of diabetic nephropathy ${ }^{(2)}$. Many studies have demonstrated that abnormal inflammatory responses including macrophage infiltration and overexpression of pro-inflammatory cytokines are present in the diabetic kidney ${ }^{(3)}$. Moreover, hyperglycaemia-induced generation of reactive oxygen species (ROS) is associated with inflammation by activating transcription factors such as NF- $\kappa B^{(4)}$. Activation of NF- $\kappa B$ increases TNF- $\alpha$, IL- $1 \beta$, transforming growth factor- $\beta 1$ and vascular endothelial growth factor. These pro-inflammatory cytokines and growth factors involved in the direct damage of kidneys, glomerulosclerosis and angiogenesis thus stimulate the development of diabetic nephropathy. Indeed, many studies have revealed that lipid peroxidation accelerated by oxidative stress is increased in diabetic renal glomerular lesions ${ }^{(5)}$. Although the involvement of inflammatory processes in the development and progression of diabetic nephropathy has been recognised, intervention for inflammation in the diabetic kidney is practically unknown.

Some studies have shown that diabetic patients have a significant deficiency of antioxidant activity, which may cause high vulnerability on oxidative stress and the development of diabetic complications. Plasma antioxidant status, including total radical-trapping antioxidant capacity and the levels of

Abbreviations: Comb, diabetic mice fed a $0.5 \mathrm{~g}$ vitamin C/100 g diet, $0.5 \mathrm{~g}$ vitamin E/ $100 \mathrm{~g}$ diet and $0.5 \mathrm{~g} N$-acetylcysteine/100 g diet; CON, non-diabetic control mice fed an AIN 93G Rodent purified diet; COX-2, cyclo-oxygenase-2; CRP, C-reactive protein; DM, diabetic mice fed an AIN 93G Rodent purified diet; iNOS, inducible NO synthase; NAC, $N$-acetylcysteine; NAC group, diabetic mice fed a $0.5 \mathrm{~g} N$-acetylcysteine/ $100 \mathrm{~g}$ diet; pI $\mathrm{B} \alpha$, phosphorylated IкB $\alpha$; ROS, reactive oxygen species; SOD, superoxide dismutase; TBARS, thiobarbituric acid-reacting substances; VCE, diabetic mice fed a $0.5 \mathrm{~g}$ vitamin $\mathrm{C} / 100 \mathrm{~g}$ diet and $0.5 \mathrm{~g}$ vitamin $\mathrm{E} / 100 \mathrm{~g}$ diet.

* Corresponding author: Y. Lim, fax +82 2961 0261, email ylim@khu.ac.kr 
uric acid, vitamin A, vitamin C or vitamin E, was decreased in diabetes ${ }^{(6-9)}$. In previous studies, nutrients such as $\alpha$ tocopherol, taurine, $N$-acetylcysteine (NAC) or $\alpha$-lipoic acid have improved glucose disposal, suppressed protein kinase $\mathrm{C}$ activation and decreased oxidative stress, as well as prevented the formation of advanced glycation end products and inhibited the levels of glycated proteins ${ }^{(10-13)}$. In addition, dietary curcuminoids have a protective role through the scavenging activity of ROS produced by hyperglycaemia, and they also induce antioxidative enzymes ${ }^{(14)}$. Supplementation of NAC, a precursor of glutathione (GSH), has suppressed NF- $\mathrm{KB}$ activation properly and decreased hyperglycaemia $^{(15)}$. Vitamin C and GSH treatment have significantly decreased oxidative stress and preserved renal function in diabetic rats ${ }^{(16-18)}$. Many studies have supported the role of antioxidants in preventing the development of diabetic nephropathy ${ }^{(19-22)}$. However, single antioxidant nutrients were utilised, and their effects were limited. Furthermore, little research has been conducted using dietary antioxidant cocktails as modulators of oxidative stress and inflammatory response in diabetic nephropathy. Thus, the present study was conducted to determine and compare the individual effects of a single dietary supplementation of antioxidants with the synergetic effects of antioxidants interacting with each other, vitamin $\mathrm{C}$, vitamin $\mathrm{E}$ and/or NAC, on diabetic nephropathy through modulation of the inflammatory response. We used kidneys of diabetic mice induced by alloxan that selectively devastates the insulin-producing $\beta$-cells in the pancreas ${ }^{(23)}$ to examine the effects of dietary antioxidant supplementation on renal inflammation and temporal expression levels of $\mathrm{Cu}-\mathrm{Zn}$ superoxide dismutase (SOD), Mn-SOD, haeme oxygenase-1, phosphorylated ІкB $\alpha$ $(\mathrm{pI} \kappa \mathrm{B} \alpha)$, inducible NO synthase (iNOS), cyclo-oxygenase-2 $(\mathrm{COX}-2)$ and $\mathrm{C}$-reactive protein (CRP) proteins.

\section{Experimental methods}

\section{Animals induced with diabetes mellitus}

Female ICR (CD-1) mice (4 weeks old) were purchased from Daehan Biolink Company, Limited (Incheon, Republic of Korea). Mice were individually housed in polycarbonate cages with wire tops in a room maintained at $22 \pm 1^{\circ} \mathrm{C}$ and $50 \pm 1 \%$ humidity on a $12 \mathrm{~h}$ light $-12 \mathrm{~h}$ dark cycle with free access to water and a chow diet for 1 week. Diabetes was induced by alloxan monohydrate $(180 \mathrm{mg} / \mathrm{kg}$ body weight, intraperitoneal injection; Sigma-Aldrich, St Louis, MO, USA) in a saline solution. Non-diabetic control mice were injected with saline. After $5 \mathrm{~d}$, the induction of diabetes was confirmed by measuring fasting blood glucose levels. Body weights and blood glucose levels were measured once a week. Glucose concentration was measured by Accu-Chek sensor (Roche Diagnostics Company Limited, Seoul, Republic of Korea) in blood obtained from tail veins at the same time to minimise the effect of diurnal fluctuation. All mice were used in accordance with animal protocols approved by the Kyung Hee University Institutional Animal Care and Use Committee.

\section{Experimental diets}

Mice with a fasting blood glucose level $\geq 2500 \mathrm{mg} / \mathrm{l}$ were used for the study. Mice were divided into five groups that were fed different antioxidant supplementation: (1) group 1 (CON) non-diabetic control mice fed an AIN 93G Rodent purified diet (Research Diets, New Brunswick, NJ, USA), (2) group 2 (DM) - diabetic mice fed an AIN 93G Rodent purified diet, (3) group 3 (NAC) - diabetic mice fed a $0.5 \mathrm{~g} \mathrm{NAC} / 100 \mathrm{~g}$ diet (Sigma grade, $\geq 99 \%$; Sigma-Aldrich), (4) group 4 (VCE) - diabetic mice fed a $0.5 \mathrm{~g}$ vitamin $\mathrm{C} / 100 \mathrm{~g}$ diet (L-ascorbic acid, $\geq 99.0 \%$, crystalline; Sigma-Aldrich) and $0.5 \mathrm{~g}$ vitamin $\mathrm{E} / 100 \mathrm{~g}$ diet $((+/-) \alpha$-tocopherol, synthetic, $\geq 96 \%$; SigmaAldrich), (5) group 5 (Comb) - diabetic mice fed a $0.5 \mathrm{~g}$ vitamin $\mathrm{C} / 100 \mathrm{~g}$ diet, $0.5 \mathrm{~g}$ vitamin $\mathrm{E} / 100 \mathrm{~g}$ diet and $0.5 \mathrm{~g} \mathrm{NAC} /$ $100 \mathrm{~g}$ diet. All mice were fed the treatment diets and water ad libitum, throughout the experimental period (8 weeks).

\section{Sample collection and preparation}

Mice were killed under light diethyl ether anaesthesia. Blood samples were collected by cardiac puncture into heparincontaining tubes and centrifuged at $3000 \mathrm{rpm}$ for $10 \mathrm{~min}$ at $4^{\circ} \mathrm{C}$. The kidneys were excised and rinsed in saline and stored at $-80^{\circ} \mathrm{C}$ until processed.

\section{Measurement of lipid peroxidation product in tissue}

Kidney thiobarbituric acid-reacting substance (TBARS) levels were measured as an index of lipid peroxidation. This process was assayed according to the method of Ohkawa et al. ${ }^{(24)}$. Briefly, $0 \cdot 1 \mathrm{~g}$ kidney was homogenated in a $0 \cdot 15 \mathrm{M}-\mathrm{KCl}$ buffer. Samples $(200 \mu \mathrm{l})$ were added to $200 \mu \mathrm{l}$ of $8 \cdot 1 \%$ SDS and placed in room temperature for $10 \mathrm{~min}$, and $3 \mathrm{ml}$ of a $20 \%$ acetic acid- $-0.8 \%$ thiobarbituric acid mixture along with $600 \mu \mathrm{l}$ of distilled water were added. The mixture was heated at $95^{\circ} \mathrm{C}$ for $1 \mathrm{~h}$ in a boiling water-bath. After cooling, $1 \mathrm{ml}$ distilled water and $5 \mathrm{ml}$ mixture of $n$-butanol and pyridine were added and shaken vigorously. After the mixture was centrifuged at $4000 \mathrm{rpm}$ for $10 \mathrm{~min}$, the absorbance of the supernatant was measured at $532 \mathrm{~nm}$ using 1,1,3,3-tetramethoxypropane (Sigma-Aldrich) as an external criterion.

\section{Renal function test}

Renal functions in diabetic kidneys were assessed by measuring the blood urea N (AM 165; Asan Pharmaceutical Company Limited, Seoul, Republic of Korea) and plasma creatinine levels (DICT-500; Bioassay Systems, Inc., Hayward, CA, USA) using commercial kits, according to the manufacturer's manual. Reaction end products were read immediately at $580 \mathrm{~nm}$ (blood urea N) and $510 \mathrm{~nm}$ (creatinine) using an ELISA reader.

\section{Western blotting assay}

Kidney $(0 \cdot 1 \mathrm{~g})$ was homogenised in a lysis buffer (containing Trizma base, $\mathrm{NaCl}, 10 \% \mathrm{NP} 40,10 \%$ Na-dedoxycholate, $100 \mathrm{~mm}-\mathrm{EDTA}$ and $10 \%$ SDS) with protease inhibitor (1:200; 
Sigma-Aldrich) and centrifuged at $14000 \mathrm{rpm}$ for $30 \mathrm{~min}$. The sample $(60 \mu \mathrm{g}$ protein) was separated on a $10 \%$ SDS PAGE and then transferred to membranes. After blocking for $1 \mathrm{~h}$ in $5 \%$ skimmed milk, the membranes were incubated with specific primary antibodies against CuZn-SOD (1:500; Santa Cruz Biotechnology, Santa Cruz, CA, USA), Mn-SOD (1:5000; Stressgen, Victoria, BC, Canada), HO-1 (1:1500; Stressgen), pIкB $\alpha$ (1:200; Santa Cruz Biotechnology), iNOS (1:2000; Stressgen), COX-2 (1:250; Transduction Laboratories, Lexington, KY, USA), CRP (1:400; Abcam, Cambridge, MA, USA) and $\beta$-actin (1:800; Santa Cruz Biotechnology) for overnight at $4{ }^{\circ} \mathrm{C}$, and then incubated with secondary antibodies for $1 \mathrm{~h}$ at room temperature. The blots were detected by enhanced chemiluminescence using an enhanced chemiluminescence solution and measured by the ImageJ program (National Institutes of Health, Bethesda, MD, USA. The target protein expression levels were normalised by $\beta$-actin protein expression in each sample.

\section{Statistical analysis}

All values are expressed as means with their standard errors. Data were analysed by one-way ANOVA using SPSS version 12.0 software (SPSS, Inc., Chicago, IL, USA), and then differences among means were analysed using Duncan's test. The relationships among blood glucose levels, TBARS, blood urea $\mathrm{N}$ and creatinine levels were evaluated by Pearson's correlation coefficients. For all tests, differences were considered significant at $P$ values of $<0 \cdot 05,<0 \cdot 01$ and $<0 \cdot 001$.

\section{Results}

\section{Body weight}

As shown in Fig. 1, the CON group revealed a significantly higher body-weight gain than all diabetic groups (DM, NAC, VCE and Comb) throughout the experimental periods,

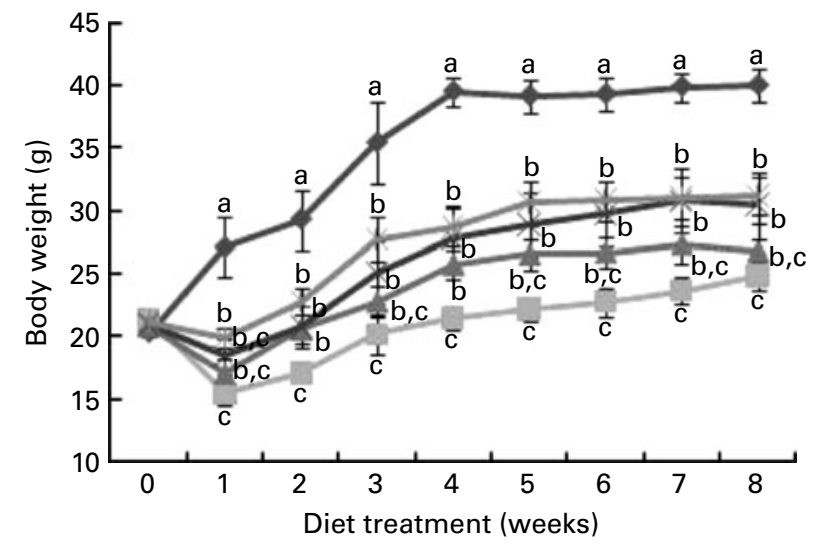

Fig. 1. Effects of dietary antioxidant supplementation on body-weight change in alloxan-induced diabetic mice. CON (control mice, - -), DM (diabetic control mice, --), NAC ( $\mathrm{N}$-acetylcysteine, - - ) $(0.5 \mathrm{~g} \mathrm{NAC} / 100 \mathrm{~g}$ dietsupplemented diabetic mice), VCE $(\rightarrow-)(0.5 \mathrm{~g}$ vitamin $\mathrm{C} / 100 \mathrm{~g}$ diet and $0.5 \mathrm{~g}$ vitamin E/100 g diet-supplemented diabetic mice) and Comb $(*)(0.5 \mathrm{~g}$ vitamin $\mathrm{C} / 100 \mathrm{~g}$ diet, $0.5 \mathrm{~g}$ vitamin $\mathrm{E} / 100 \mathrm{~g}$ diet and $0.5 \mathrm{~g} \mathrm{NAC} / 100 \mathrm{~g}$ dietsupplemented diabetic mice). Values are means, with their standard errors represented by vertical bars. ${ }^{\mathrm{a}, \mathrm{b}, \mathrm{c}}$ Mean values with unlike letters were significantly different $(P<0.05)$.

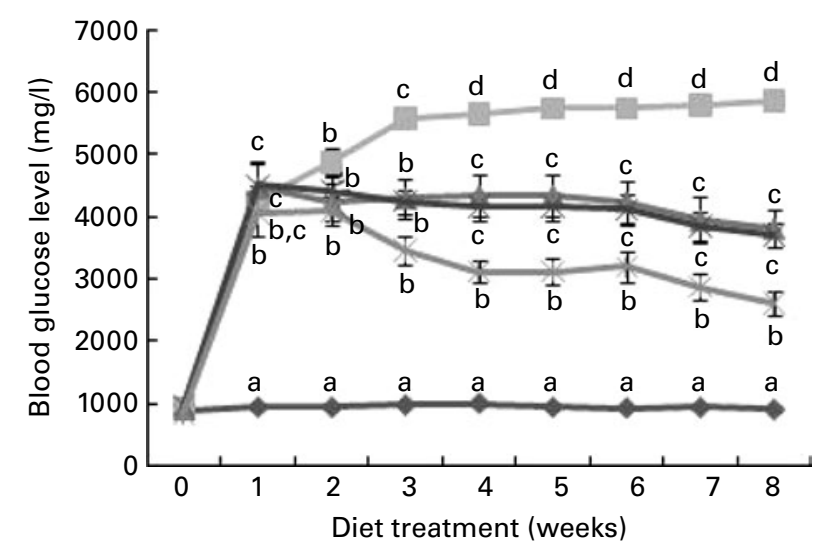

Fig. 2. Effects of dietary antioxidant supplementation on blood glucose levels in alloxan-induced diabetic mice. CON (control mice, --$)$, DM (diabetic control mice, - -), NAC ( $\mathrm{N}$-acetylcysteine, -$)(0.5 \mathrm{~g} \mathrm{NAC} / 100 \mathrm{~g}$ dietsupplemented diabetic mice), VCE $(*)(0.5 \mathrm{~g}$ vitamin $\mathrm{C} / 100 \mathrm{~g}$ diet and $0.5 \mathrm{~g}$ vitamin E/100 g diet-supplemented diabetic mice) and Comb $\left(*_{-}\right)(0.5 \mathrm{~g}$ vitamin $\mathrm{C} / 100 \mathrm{~g}$ diet, $0.5 \mathrm{~g}$ vitamin $\mathrm{E} / 100 \mathrm{~g}$ diet and $0.5 \mathrm{~g} \mathrm{NAC} / 100 \mathrm{~g}$ dietsupplemented diabetic mice). Values are means, with their standard errors represented by vertical bars. ${ }^{a, b, c, d}$ Mean values with unlike letters were significantly different $(P<0.05)$.

but the VCE and Comb groups improved the body-weight gain compared with the DM group by 123 and $125 \%$ $(P<0.05)$, respectively.

\section{Blood glucose levels}

All diabetic groups regardless of dietary antioxidant treatment showed significantly higher blood glucose levels than the CON group after alloxan was injected ( $P<0 \cdot 05$; Fig. 2$)$. After 3 weeks of diet treatment, blood glucose levels of all diabetic mice supplemented with dietary antioxidants (NAC, VCE, and Comb) were significantly lower compared with that of the DM group by 77,76 and $62 \%(P<0 \cdot 05)$, respectively. Furthermore, in the Comb group, the blood glucose level was significantly lower after 4 weeks of dietary antioxidant treatment compared with those of the NAC and VCE groups $(P<0.05)$.

\section{Lipid peroxidation levels in diabetic kidneys}

The effects of dietary antioxidant supplementation on TBARS levels were evaluated in the kidneys. As shown in Table 1, the renal TBARS level of the DM group was significantly higher compared with that of the CON group ( 1.6 times, $P<0.05$ ), but not in dietary antioxidant-supplemented diabetic mice.

\section{Blood urea nitrogen and plasma creatinine levels}

To determine the effect of dietary antioxidant supplementation on the protection of renal tissue against alloxan-induced diabetes, the levels of blood urea $\mathrm{N}$ and creatinine were determined. Experimental findings showed that the levels of blood urea $\mathrm{N}$ (two times) and creatinine (twelve times) in the DM group were significantly higher than those of the CON group $(P<0.01$ and $<0 \cdot 001)$. However, dietary antioxidant supplementation effectively ameliorated the increases in 
Table 1. Levels of thiobarbituric-acid reacting substances (TBARS), blood urea nitrogen (BUN) and creatinine in control and diabetic mice with various dietary treatments for 8 weeks

(Mean values with their standard errors)

\begin{tabular}{|c|c|c|c|c|c|c|}
\hline & \multicolumn{2}{|c|}{ Kidney } & \multicolumn{4}{|c|}{ Plasma } \\
\hline & \multicolumn{2}{|c|}{$\begin{array}{l}\text { TBARS level } \\
\text { (nmol/g tissue) }\end{array}$} & \multicolumn{2}{|c|}{ BUN (mg/l) } & \multicolumn{2}{|c|}{ Creatinine $(\mathrm{mg} / \mathrm{l})$} \\
\hline & Mean & SEM & Mean & SEM & Mean & SEM \\
\hline CON & 17.067 & 0.761 & 284.74 & 1.31 & $6 \cdot 12$ & 0.66 \\
\hline DM & $27 \cdot 192^{*}$ & 5.888 & $539 \cdot 91^{\star *}$ & $40 \cdot 89$ & $74 \cdot 82^{\star \star \star}$ & $10 \cdot 16$ \\
\hline NAC & $15 \cdot 067$ & 1.697 & $414.08^{* \star}+\dagger \dagger$ & $25 \cdot 07$ & 11.88 & 4.46 \\
\hline VCE & $12 \cdot 504$ & 0.991 & $352.23+t \dagger$ & $19 \cdot 04$ & 11.96 & 1.98 \\
\hline Comb & $12 \cdot 108$ & 0.982 & $330.87+t \dagger$ & 12.29 & 6.86 & 0.90 \\
\hline
\end{tabular}

CON, non-diabetic control mice fed an AIN 93G Rodent purified diet; DM, diabetic mice fed an AIN 93G Rodent purified diet; NAC, diabetic mice fed a $0.5 \mathrm{~g} \mathrm{~N}$-acetylcysteine $/ 100 \mathrm{~g}$ diet; VCE, diabetic mice fed a $0.5 \mathrm{~g}$ vitamin $\mathrm{C} / 100 \mathrm{~g}$ diet and $0.5 \mathrm{~g}$ vitamin $\mathrm{E} / 100 \mathrm{~g}$ diet; Comb, diabetic mice fed a $0.5 \mathrm{~g}$ vitamin $\mathrm{C} / 100 \mathrm{~g}$ diet, $0.5 \mathrm{~g}$ vitamin $\mathrm{E} / 100 \mathrm{~g}$ diet and $0.5 \mathrm{~g} \mathrm{NAC} / 100 \mathrm{~g}$ diet.

Mean values were significantly different from those of the CON group: ${ }^{\star} P<0.05$, ${ }^{\star \star} P<0.01,{ }^{\star \star \star} P<0.001$

Relationships among thiobarbituric acid-reacting substances, blood urea nitrogen and creatinine levels

TBARS levels were positively correlated with blood urea $\mathrm{N}$ and creatinine levels in CON and diabetic mice treated with different antioxidant-supplemented diets $(P<0 \cdot 05$; Table 3$)$.

\section{Oxidative stress- and inflammatory response-related protein expression in diabetic kidneys}

To establish the effects of dietary antioxidant supplementation on renal inflammation in diabetic mice, we investigated the expression levels of oxidative stress- and inflammatory

Table 2. Relationships among blood glucose levels, thiobarbituric acidreacting substances (TBARS), blood urea nitrogen (BUN) and creatinine levels in control and diabetic mice with various dietary treatments for 8 weeks

(Pearson's correlation coefficients)

\begin{tabular}{lccc}
\hline & TBARS & BUN & Creatinine \\
\hline Blood glucose $\dagger$ & $0.405^{*}$ & $0.744^{\star *}$ & $0.705^{\star *}$ \\
\hline
\end{tabular}

Values were significantly different: ${ }^{\star} P<0.05$, ${ }^{\star *} P<0.01$.

†Blood glucose levels in the last week of the experiment (after 8 weeks of the diet treatment)
Table 3. Relationships among thiobarbituric acid-reacting substances (TBARS), blood urea nitrogen (BUN) and creatinine levels in control and diabetic mice with various dietary treatments for 8 weeks

(Pearson's correlation coefficients)

\begin{tabular}{lcc}
\hline & BUN & Creatinine \\
\hline TBARS & $0.518^{\star *}$ & $0.405^{\star}$ \\
\hline${ }^{*} P<0.05^{* \star} P<0.01$ & &
\end{tabular}

response-related proteins in mouse kidneys using Western blotting. The expression levels of CuZn-SOD are shown in Fig. 3. We found a higher protein expression of CuZn-SOD in the kidneys of the DM, NAC and VCE groups than in those of the CON group $(P<0.05)$ but in the Comb group, the levels of CuZn-SOD returned to a normal state. However Mn-SOD protein expression did not significantly differ in all experimental groups (data not shown). HO-1 protein expression in the kidneys was considerably down-regulated in the DM group compared with the CON group $(P<0.05)$, but dietary antioxidant supplementation inhibited from decreasing HO-1 protein expression to a level consistent with the CON group (Fig. 4). The level of $\mathrm{pI \kappa \textrm {B } \alpha}$ protein was significantly higher in the kidneys of the DM group compared with that of the CON group $(P<0 \cdot 05$; Fig. 5). Dietary antioxidant-supplemented diabetic mice significantly reduced the $\mathrm{pI \kappa \textrm {B } \alpha}$ protein levels, and notably, the antioxidant cocktail-supplemented VCE and Comb groups decreased to a greater amount the $\mathrm{pI \kappa \textrm {B } \alpha}$ protein level than the single antioxidant-supplemented NAC group $(P<0.05)$. While there was no difference in the expression levels of iNOS among the CON,
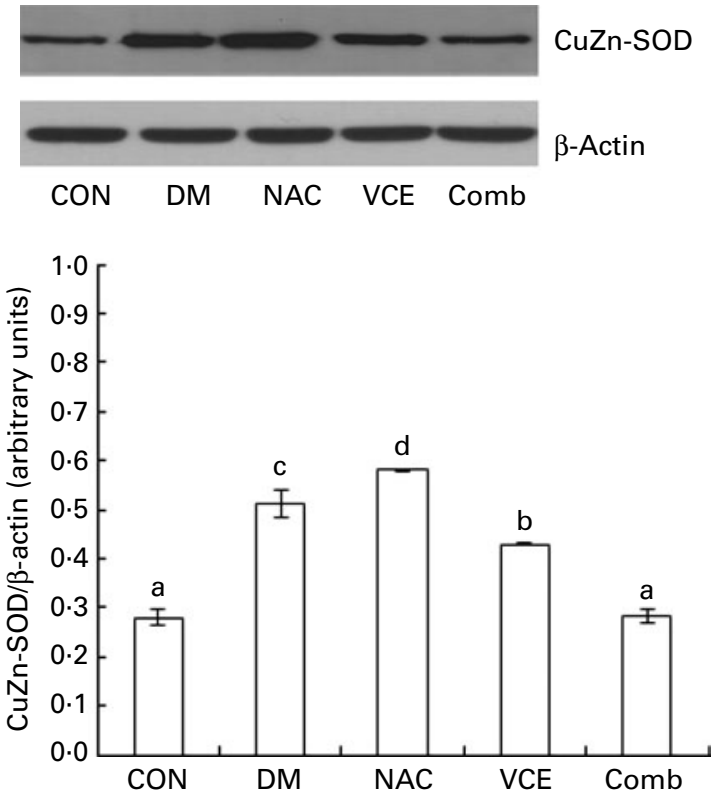

Fig. 3. Effects of dietary antioxidant supplementation on protein expression levels of $\mathrm{Cu}-\mathrm{Zn}$ superoxide dismutase (CuZn-SOD) in alloxan-induced diabetic kidney. CON (control mice), DM (diabetic control mice), NAC ( $\mathrm{N}$-acetylcysteine, $0.5 \mathrm{~g} \mathrm{NAC} / 100 \mathrm{~g}$ diet-supplemented diabetic mice), VCE $(0.5 \mathrm{~g}$ vitamin $\mathrm{C} / 100 \mathrm{~g}$ diet and $0.5 \mathrm{~g}$ vitamin $\mathrm{E} / 100 \mathrm{~g}$ diet-supplemented diabetic mice) and Comb $(0.5 \mathrm{~g}$ vitamin $\mathrm{C} / 100 \mathrm{~g}$ diet, $0.5 \mathrm{~g}$ vitamin $\mathrm{E} / 100 \mathrm{~g}$ diet and $0.5 \mathrm{~g} \mathrm{NAC} / 100 \mathrm{~g}$ diet-supplemented diabetic mice). Values are means, with their standard errors represented by vertical bars. ${ }^{a, b, c, d}$ Mean values with unlike letters were significantly different $(P<0.05)$. 

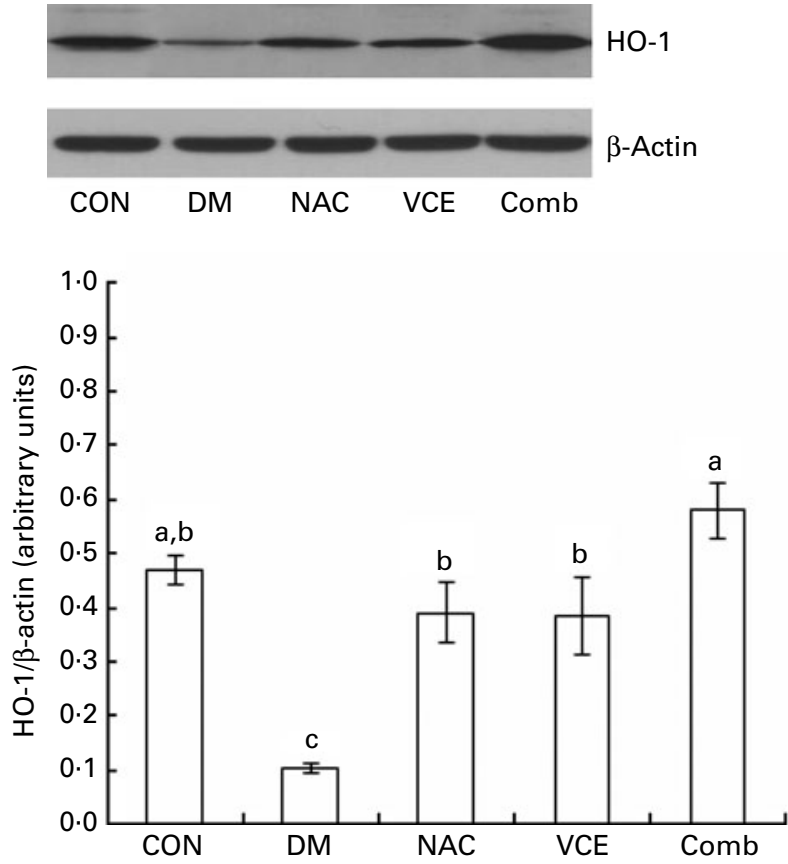

Fig. 4. Effects of dietary antioxidant supplementation on protein expression levels of haeme oxygenase-1 (HO-1) in alloxan-induced diabetic kidney. CON (control mice), DM (diabetic control mice), NAC ( $N$-acetylcysteine, $0.5 \mathrm{~g}$ $\mathrm{NAC} / 100 \mathrm{~g}$ diet-supplemented diabetic mice), VCE $(0.5 \mathrm{~g}$ vitamin $\mathrm{C} / 100 \mathrm{~g}$ diet and $0.5 \mathrm{~g}$ vitamin $E / 100 \mathrm{~g}$ diet-supplemented diabetic mice) and Comb $(0.5 \mathrm{~g}$ vitamin $\mathrm{C} / 100 \mathrm{~g}$ diet, $0.5 \mathrm{~g}$ vitamin $\mathrm{E} / 100 \mathrm{~g}$ diet and $0.5 \mathrm{~g} \mathrm{NAC} / 100 \mathrm{~g}$ dietsupplemented diabetic mice). Values are means, with their standard errors represented by vertical bars. ${ }^{\mathrm{a}, \mathrm{b}, \mathrm{c}}$ Mean values with unlike letters were significantly different $(P<0.05)$.

DM, NAC and VCE groups, the Comb group significantly diminished the iNOS protein levels $(P<0.05$; Fig. 6). As shown in Fig. 7, the expression levels of COX-2 protein were significantly higher in the DM group compared with those of the CON group $(P<0.05)$. On the other hand, the COX-2 levels were remarkably reduced in dietary antioxidant-supplemented diabetic mice $(P<0 \cdot 05)$. The expression levels of CRP were lower in the Comb group compared with those in the DM group ( $P<0.05$; Fig. 8).

\section{Discussion}

In these experiments, we investigated the effects of dietary antioxidant supplementation on molecular events and kidney function in diabetic nephropathy induced by alloxan that damages pancreatic $\beta$ cells $^{(23)}$. Our data demonstrated that lipid peroxidation in kidneys and renal function were improved by dietary antioxidant supplementation. Moreover, antioxidant cocktail treatment attenuated not only blood glucose levels but also specific markers of the inflammatory response, including protein levels of the $\mathrm{pI \kappa} B \alpha$, inflammation-mediated enzymes, iNOS and COX-2, and the acutephase protein, CRP.

In the present study, the body weights of the VCE and Comb groups, rather than the NAC group, were higher compared with that of the DM group. A previous study has shown that the body weights of diabetic rats supplemented with vitamin $\mathrm{C}$ or vitamin $\mathrm{E}$ did not differ from those of untreated diabetic rats, suggesting that supplementation with an antioxidant cocktail may have a positive anabolic effect by the regulation of blood glucose levels ${ }^{(25)}$. Previous studies have shown that vitamin $\mathrm{C}$, vitamin $\mathrm{E}$ or NAC significantly decreased the TBARS levels ${ }^{(26-28)}$. Moreover, our previous study showed that a short-term as well as a long-term dietary antioxidant cocktail treatment decreased TBARS levels in the diabetic kidneys ${ }^{(29)}$. However, a long-term dietary antioxidant supplementation for diabetic mice in the present study returned the levels of TBARS towards the controls' levels, which suggests that long-term antioxidant treatment is more effective in reducing oxidative stress. We demonstrated that increased renal oxidative stress represented by TBARS is positively correlated with increased renal dysfunction. Increased blood urea $\mathrm{N}$ and plasma creatinine in diabetic rats indicates progressive renal damage ${ }^{(28,30)}$. It has been previously reported that diabetic rats had a decreased renal function that is associated with the formation of reactive oxygen intermediates $^{(31)}$, suggesting that the scavenging effects of antioxidants on free radicals and the inhibition of lipid peroxidation by antioxidant treatment may play a role in improving renal dysfunction in diabetes.

We examined selective protein expressions in order to investigate the molecular mechanism through which dietary antioxidant supplementation alters the inflammatory response in diabetic nephropathy. Hyperglycaemia causes glycation of various proteins leading to the formation of superoxide radicals $\left(\mathrm{O}_{2}^{-}\right)$and thus, increased levels of free radicals are found in diabetes ${ }^{(32)}$. A previous study has shown that
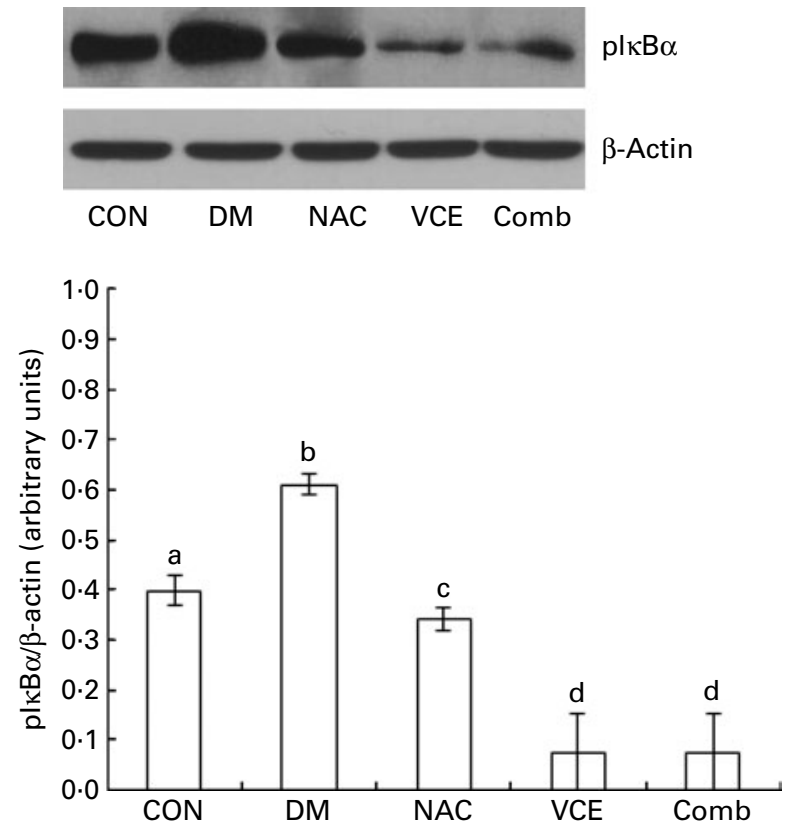

Fig. 5. Effects of dietary antioxidant supplementation on protein expression levels of phosphorylated $І_{\kappa} \mathrm{B} \alpha(\mathrm{pl \kappa} \mathrm{B} \alpha)$ in alloxan-induced diabetic kidney. CON (control mice), DM (diabetic control mice), NAC ( $N$-acetylcysteine, $0.5 \mathrm{~g}$ $\mathrm{NAC} / 100 \mathrm{~g}$ diet-supplemented diabetic mice), VCE $(0.5 \mathrm{~g}$ vitamin $\mathrm{C} / 100 \mathrm{~g}$ diet and $0.5 \mathrm{~g}$ vitamin $E / 100 \mathrm{~g}$ diet-supplemented diabetic mice), Comb (0.5 g vitamin $\mathrm{C} / 100 \mathrm{~g}$ diet, $0.5 \mathrm{~g}$ vitamin $\mathrm{E} / 100 \mathrm{~g}$ diet and $0.5 \mathrm{~g} \mathrm{NAC} / 100 \mathrm{~g}$ dietsupplemented diabetic mice). Values are means, with their standard errors represented by vertical bars. ${ }^{a, b, c, d}$ Mean values with unlike letters were significantly different $(P<0.05)$. 

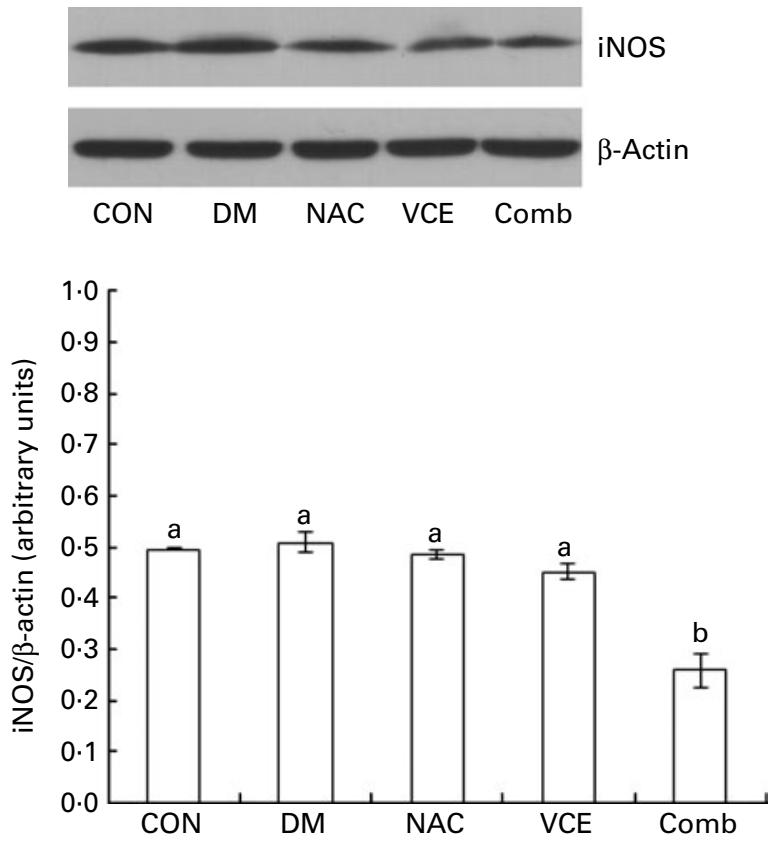

Fig. 6. Effects of dietary antioxidant supplementation on protein expression levels of inducible NO synthase (iNOS) in alloxan-induced diabetic kidney. CON (control mice), DM (diabetic control mice), NAC ( $N$-acetylcysteine, $0.5 \mathrm{~g}$ $\mathrm{NAC} / 100 \mathrm{~g}$ diet-supplemented diabetic mice), VCE $(0.5 \mathrm{~g}$ vitamin $\mathrm{C} / 100 \mathrm{~g}$ diet and $0.5 \mathrm{~g}$ vitamin $\mathrm{E} / 100 \mathrm{~g}$ diet-supplemented diabetic mice) and Comb $(0.5 \mathrm{~g}$ vitamin $\mathrm{C} / 100 \mathrm{~g}$ diet, $0.5 \mathrm{~g}$ vitamin $\mathrm{E} / 100 \mathrm{~g}$ diet and $0.5 \mathrm{~g} \mathrm{NAC} / 100 \mathrm{~g}$ diet-supplemented diabetic mice). Values are means, with their standard errors represented by vertical bars. ${ }^{a, b}$ Mean values with unlike letters were significantly different $(P<0.05)$
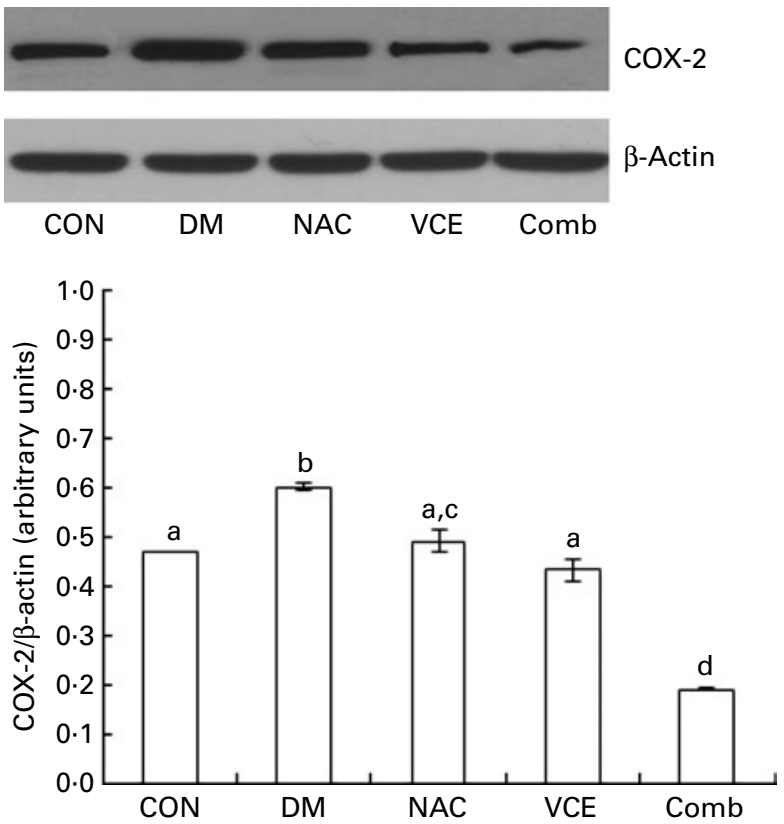

Fig. 7. Effects of dietary antioxidant supplementation on protein expression levels of cyclo-oxygenase-2 (COX-2) in alloxan-induced diabetic kidney. CON (control mice), DM (diabetic control mice), NAC ( $N$-acetylcysteine, $0.5 \mathrm{~g}$ $\mathrm{NAC} / 100 \mathrm{~g}$ diet-supplemented diabetic mice), VCE $(0.5 \mathrm{~g}$ vitamin $\mathrm{C} / 100 \mathrm{~g}$ diet and $0.5 \mathrm{~g}$ vitamin E/100 g diet-supplemented diabetic mice) and Comb $(0.5 \mathrm{~g}$ vitamin $\mathrm{C} / 100 \mathrm{~g}$ diet, $0.5 \mathrm{~g}$ vitamin $\mathrm{E} / 100 \mathrm{~g}$ diet and $0.5 \mathrm{~g} \mathrm{NAC} / 100 \mathrm{~g}$ diet-supplemented diabetic mice). Values are means, with their standard errors represented by vertical bars. ${ }^{a, b, c, d}$ Mean values with unlike letters were significantly different $(P<0.05)$.
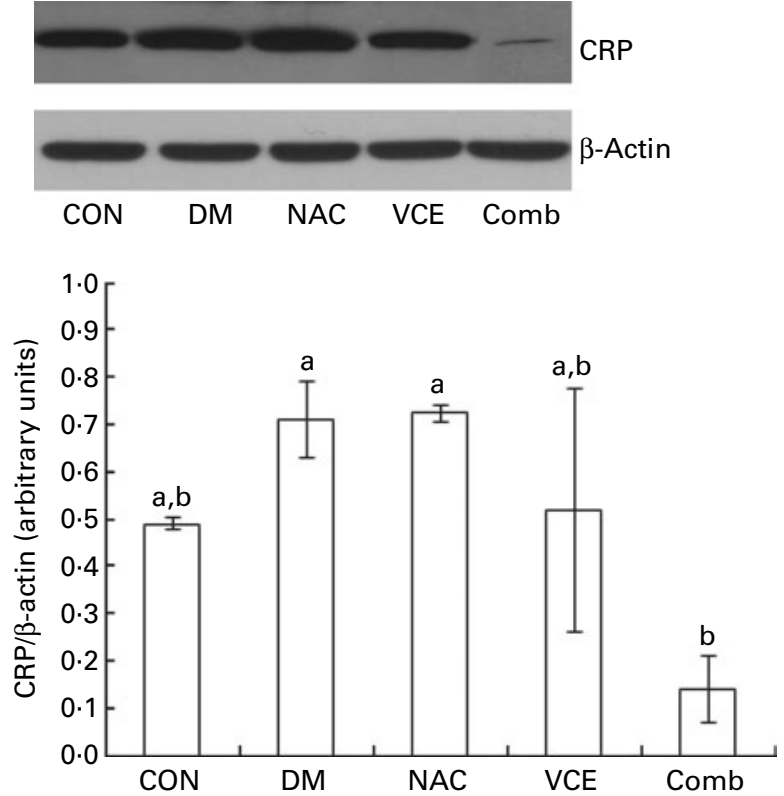

Fig. 8. Effects of dietary antioxidant supplementation on protein expression levels of $\mathrm{C}$-reactive protein (CRP) in alloxan-induced diabetic kidney. CON (control mice), DM (diabetic control mice), NAC ( $N$-acetylcysteine, $0.5 \mathrm{~g}$ $\mathrm{NAC} / 100 \mathrm{~g}$ diet-supplemented diabetic mice), VCE $(0.5 \mathrm{~g}$ vitamin $\mathrm{C} / 100 \mathrm{~g}$ diet and $0.5 \mathrm{~g}$ vitamin $E / 100 \mathrm{~g}$ diet-supplemented diabetic mice) and Comb $(0.5 \mathrm{~g}$ vitamin $\mathrm{C} / 100 \mathrm{~g}$ diet, $0.5 \mathrm{~g}$ vitamin $\mathrm{E} / 100 \mathrm{~g}$ diet and $0.5 \mathrm{~g} \mathrm{NAC} / 100 \mathrm{~g}$ dietsupplemented diabetic mice). Values are means, with their standard errors represented by vertical bars. ${ }^{a, b}$ Mean values with unlike letters were significantly different $(P<0.05)$.

ROS-scavenging enzymes, such as SOD activity, were significantly higher in diabetic rats than in non-diabetic ones $^{(33)}$. The result, which is similar to our present study, comes from the phenomenon of physiological adaptation to an increase in ROS scavengers caused by diabetes by means of activated SOD.

HO-1 is induced under a wide variety of conditions associated with oxidative stress and is regarded as a protective response to oxidants ${ }^{(34)}$. The lower protein expression of HO-1 that we observed in diabetic nephropathy seems to be in contrast to findings of other studies ${ }^{(34-36)}$, which showed an increase in HO-1 protein levels in diabetes and a paradoxical decrease in HO-1 activity. In the present study, we reported that HO-1 protein levels were restored in the dietary antioxidant-supplemented groups. An increase in HO-1 will increase anti-inflammatory and antioxidant capacities.

$\mathrm{NF}-\kappa \mathrm{B}$ is composed of a family of inducible transcription factors that serve as essential regulators of the host immune and inflammatory response ${ }^{(37)}$. NF- $\mathrm{kB}$ activation in the renal tissue of diabetic rats ${ }^{(38)}$, as well as the fact that advanced glycation end products induce oxidative stress and activate NF-кB in mesangial cells ${ }^{(39)}$, has been reported. Other studies have reported that NF- $\mathrm{B}$ binding activity increases in peripheral blood mononuclear cells in uncontrolled diabetic patients ${ }^{(40)}$, and that this activation is oxidative stress sensitive and correlates with the degree of diabetic nephropathy, suggesting that oxidative stress plays an important role in the development of diabetic complications ${ }^{(41)}$. Furthermore, NF- $\mathrm{kB}$ promotes the expression of enzymes which contribute 
to the pathogenesis of the inflammatory response, including iNOS and COX-2 $2^{(42)}$.

CRP is known to be produced in response to inflammatory cytokines, and increased levels are considered as significant inflammatory states ${ }^{(43)}$. It is known that increased CRP levels are associated with diabetes and its complications such as nephropathy ${ }^{(44)}$. The present study showed that dietary antioxidant supplementation regulated the expressions of iNOS, COX-2 and CRP proteins by controlling the expression of $\mathrm{pI \kappa \textrm {B }} \alpha$ protein. Particularly, these results showed that interacting with different antioxidants, including NAC, vitamin C and vitamin $\mathrm{E}$, amplified their effects.

Based on the results, ROS generation caused by hyperglycaemia increased oxidative stress and stimulated NF- $\mathrm{BB}$ activation in diabetic kidneys and decreased their function by increasing the inflammatory response. We found that a long-term antioxidant cocktail supplementation reduced the degree of diabetes and prevented the progress of diabetic nephropathy. This result encouraged us to believe that a long-term antioxidant cocktail supplementation may have a potential benefit in preventing and improving diabetic nephropathy by regulating renal inflammation. However, further study is required to clarify the mechanisms involved in the development of diabetic complications such as nephropathy. Moreover, further research should be conducted to verify the safe concentration needed for each antioxidant when employed in clinical settings for application to human studies.

\section{Acknowledgements}

The present study was supported by a grant from the Kyung Hee University (KHU-20080576). Y. L. conceptualised the research, supervised the laboratory analysis and wrote the manuscript for important intellectual content. N.-Y. P. wrote the manuscript and performed the laboratory work. S.-K. P. performed the laboratory work. All authors reviewed the final manuscript. There are no conflicts of interest to declare.

\section{References}

1. Soman SS \& Soman AS (2009) Diabetic nephropathy. http:// emedicine.medscape.com/article/238946 over.

2. Schrijvers BF, De Vriese AS \& Flyvbjerg A (2004) From hyperglycemia to diabetic kidney disease: the role of metabolic, hemodynamic, intracellular factors and growth factors/ cytokines. Endocr Rev 25, 971-1010.

3. Chow F, Ozols E, Nikolic-Paterson DJ, et al. (2004) Macrophages in mouse type 2 diabetic nephropathy: correlation with diabetic state and progressive renal injury. Kidney Int 65, 116-128.

4. Ha H, Yu MR, Choi YJ, et al. (2002) Role of high glucoseinduced nuclear factor-kappaB activation in monocyte chemoattractant protein-1 expression by mesangial cells. $J$ Am Soc Nephrol 13, 894-902.

5. Horie K, Miyata T, Maeda K, et al. (1997) Immunohistochemical colocalization of glycoxidation products and lipid peroxidation products in diabetic renal glomerular lesions. Implication for glycoxidative stress in the pathogenesis of diabetic nephropathy. J Clin Invest 100, 2995-3004.
6. Maxwell SR, Thomason H, Sandler D, et al. (1997) Poor glycaemic control is associated with reduced serum free radical scavenging (antioxidant) activity in non-insulin-dependent diabetes mellitus. Ann Clin Biochem 34, 638-644.

7. Maxwell SR, Thomason H, Sandler D, et al. (1997) Antioxidant status in patients with uncomplicated insulin-dependent and non-insulin-dependent diabetes mellitus. Eur J Clin Invest 27, 484-490.

8. Nourooz-Zadeh J, Rahimi A, Tajaddini-Sarmadi J, et al. (1997) Relationships between plasma measures of oxidative stress and metabolic control in NIDDM. Diabetologia $\mathbf{4 0}$, 647-653.

9. Santini SA, Marra G, Giardina B, et al. (1997) Defective plasma antioxidant defenses and enhanced susceptibility to lipid peroxidation in uncomplicated IDDM. Diabetes 46, $1853-1858$.

10. Studer RK, Craven PA \& DeRubertis FR (1997) Antioxidant inhibition of protein kinase C-signaled increases in transforming growth factor-beta in mesangial cells. Metabolism 46, 918-925.

11. Tada H, Ishii H \& Isogai S (1997) Protective effect of D-alphatocopherol on the function of human mesangial cells exposed to high glucose concentrations. Metabolism $\mathbf{4 6}$, 779-784.

12. Giardino I, Edelstein D \& Brownlee M (1996) BCL-2 expression or antioxidants prevent hyperglycemia-induced formation of intracellular advanced glycation endproducts in bovine endothelial cells. J Clin Invest 97, 1422-1428.

13. Bierhaus A, Chevion S, Chevion M, et al. (1997) Advanced glycation end product-induced activation of NF-kappaB is suppressed by alpha-lipoic acid in cultured endothelial cells. Diabetes 46, 1481-1490.

14. Osawa T \& Kato Y (2005) Protective role of antioxidative food factors in oxidative stress caused by hyperglycemia. Ann N Y Acad Sci 1043, 440-451.

15. Ho E, Chen G \& Bray TM (1999) Supplementation of $N$-acetylcysteine inhibits NFkappaB activation and protects against alloxan-induced diabetes in CD-1 mice. Faseb $J$ 13, $1845-1854$.

16. Lee EY, Lee MY, Hong SW, et al. (2007) Blockade of oxidative stress by vitamin $\mathrm{C}$ ameliorates albuminuria and renal sclerosis in experimental diabetic rats. Yonsei Med J 48, 847-855.

17. Ueno Y, Kizaki M, Nakagiri R, et al. (2002) Dietary glutathione protects rats from diabetic nephropathy and neuropathy. J Nutr 132, 897-900.

18. Nakhoul FM, Miller-Lotan R, Awad H, et al. (2009) Pharmacogenomic effect of vitamin E on kidney structure and function in transgenic mice with the haptoglobin 2-2 genotype and diabetes mellitus. Am J Physiol Renal Physiol 296, F830-F838.

19. Craven PA, DeRubertis FR, Kagan VE, et al. (1997) Effects of supplementation with vitamin $\mathrm{C}$ or $\mathrm{E}$ on albuminuria, glomerular TGF-beta, and glomerular size in diabetes. $J \mathrm{Am}$ Soc Nephrol 8, 1405-1414.

20. Koya D, Lee IK, Ishii H, et al. (1997) Prevention of glomerular dysfunction in diabetic rats by treatment with D-alphatocopherol. J Am Soc Nephrol 8, 426-435.

21. Trachtman H, Futterweit S, Maesaka J, et al. (1995) Taurine ameliorates chronic streptozocin-induced diabetic nephropathy in rats. Am J Physiol 269, F429-F438.

22. Packer L, Witt EH \& Tritschler HJ (1995) Alpha-lipoic acid as a biological antioxidant. Free Radic Biol Med 19, 227-250.

23. Ramadan G, El-Beih NM \& Abd El-Ghffar EA (2009) Modulatory effects of black $v$. green tea aqueous extract 
on hyperglycaemia, hyperlipidaemia and liver dysfunction in diabetic and obese rat models. Br J Nutr 102, 1611-1619.

24. Ohkawa H, Ohishi N \& Yagi K (1979) Assay for lipid peroxides in animal tissues by thiobarbituric acid reaction. Anal Biochem 95, 351-358.

25. Kedziora-Kornatowska K, Szram S, Kornatowski T, et al. (2003) Effect of vitamin E and vitamin C supplementation on antioxidative state and renal glomerular basement membrane thickness in diabetic kidney. Nephron Exp Nephrol 95, e134-e143

26. Park SK, Park NY \& Lim Y (2009) Effects of short term antioxidant cocktail supplementation on the oxidative stress and inflammatory response of renal inflammation in diabetic mice. Korean J Nutr 42, 673-681.

27. Kuhad A \& Chopra K (2009) Attenuation of diabetic nephropathy by tocotrienol: involvement of NFkB signaling pathway. Life Sci 84, 296-301.

28. Rhoden CR, Lawrence J, Godleski JJ, et al. (2004) $N$-acetylcysteine prevents lung inflammation after short-term inhalation exposure to concentrated ambient particles. Toxicol Sci 79, 296-303.

29. Cay M, Naziroglu M, Simsek H, et al. (2001) Effects of intraperitoneally administered vitamin $\mathrm{C}$ on antioxidative defense mechanism in rats with diabetes induced by streptozotocin. Res Exp Med (Berl) 200, 205-213.

30. Renno WM, Abdeen S, Alkhalaf M, et al. (2008) Effect of green tea on kidney tubules of diabetic rats. Br J Nutr $\mathbf{1 0 0}$, 652-659.

31. Murali B \& Goyal RK (2001) Effect of chronic treatment with losartan on streptozotocin induced diabetic nephropathy. Clin Exp Hypertens 23, 513-520.

32. Signorello MG, Viviani GL, Armani U, et al. (2007) Homocysteine, reactive oxygen species and nitric oxide in type 2 diabetes mellitus. Thromb Res 120, 607-613.

33. Kim MJ, Cho SY, Lee MK, et al. (2004) Effects of Aralia elata water extracts on activities of hepatic oxygen free radical generating and scavenging enzymes in streptozotocin-induced diabetic rats. I Korean Soc Food $S c i$ Nut 33, 653-658.

34. Kruger AL, Peterson SJ, Schwartzman ML, et al. (2006) Upregulation of heme oxygenase provides vascular protection in an animal model of diabetes through its antioxidant and antiapoptotic effects. J Pharmacol Exp Ther 319, 1144-1152.

35. Nath KA (2006) Heme oxygenase-1: a provenance for cytoprotective pathways in the kidney and other tissues. Kidney Int 70, 432-443.

36. Hayashi K, Haneda M, Koya D, et al. (2001) Enhancement of glomerular heme oxygenase-1 expression in diabetic rats. Diabetes Res Clin Pract 52, 85-96.

37. Yamamoto Y \& Gaynor RB (2001) Therapeutic potential of inhibition of the NF-kappaB pathway in the treatment of inflammation and cancer. $J$ Clin Invest 107, 135-142.

38. Iwamoto M, Mizuiri S \& Tanimoto H (2001) Nuclear factorkappaB activation in streptozotocin induced diabetic rats kidneys. J Am Soc Nephrol 12, 838a.

39. Lal M, Brismar H, Eklof AC, et al. (2001) Advanced glycation endproducts induced oxidative stress and activate NF-kB, PKC in mesangial cells. J Am Soc Nephrol 12, 840a.

40. Hofmann MA, Schiekofer S, Kanitz M, et al. (1998) Insufficient glycemic control increases nuclear factor-kappa B binding activity in peripheral blood mononuclear cells isolated from patients with type 1 diabetes. Diabetes Care $\mathbf{2 1}$ 1310-1316.

41. Mohamed AK, Bierhaus A, Schiekofer S, et al. (1999) The role of oxidative stress and NF-kappaB activation in late diabetic complications. Biofactors 10, 157-167.

42. Pahl HL (1999) Activators and target genes of Rel/NF-kappaB transcription factors. Oncogene 18, 6853-6866.

43. Eklund CM (2009) Proinflammatory cytokines in CRP baseline regulation. Adv Clin Chem 48, 111-136.

44. Goldberg RB (2009) Cytokine and cytokine-like inflammation markers, endothelial dysfunction, and imbalanced coagulation in development of diabetes and its complications. J Clin Endocrinol Metab 94, 3171-3182. 